\title{
PENGEMBANGAN MEDIA VIDEO PEMBELAJARAN DENGAN MODEL ADDIE PADA MATERI TEKNIK DASAR TENDANGAN PENCAK SILAT KELAS VII SMP NEGERI 4 SUKASADA TAHUN PELAJARAN 2019/2020
}

\author{
Liberta Loviana Carolin ${ }^{1}$, I Ketut Budaya Astra², I Gede Suwiwa ${ }^{3}$
}

1,2,3 Universitas Pendidikan Ganesha

E-mail: carolinberta29@gmail.com¹, budaya.astra@undiksha.ac.id², gede.suwiwa@undiksha.ac.id³ DOI: https://doi.org/10.36526/kejaora.v5i2.934

\begin{abstract}
ABSTRAK
Tujuan dari penelitian yaitu untuk mengembangkan media video pembelajaran teknik dasar tendangan pencak silat dengan model ADDIE. Jenis penelitian ini adalah penelitian pengembangan. Prosedur pengembangan model ADDIE, yaitu: analysis, design, development, implementation dan evaluation. Validasi bahan ajar model ADDIE yaitu: uji ahli isi mata pelajaran, uji ahli media pembelajaran, uji ahli desain pembelajaran, uji coba perorangan, uji coba kelompok kecil dan uji coba kelompok besar. Teknik analisis deskriptif kualitatif dan analisis deskriptif kuantitatif adalah teknik analisis yang digunakan. Tanggapan ahli isi mata pelajaran memperoleh persentase $94 \%$ dengan kualifikasi sangat baik. Tanggapan ahli media pembelajaran memperolehpersentase $90 \%$ dengan kualifikasi sangat baik. Tanggapan ahli desain pembelajaran memperoleh presentase $94 \%$ dengan kualifikasi sangat baik. Sedangkan uji coba peserta didik tidak bisa dilakukan karena adanya pandemi covid19 yang mengharuskan peserta didik belajar dirumah secara online/daring. Hasil penelitian disimpulkan bahwa media video pembelajaran teknik dasar tendangan pencak silat layak digunakan menurut uji ahli isi mata pelajaran, uji ahli media pembelajaran dan uji ahli desain pembelajaran karena sudah memenuhi kriteria sesuai ketentuan dan sudah melaksanakan tahapan model ADDIE secara keseluruhan. Saran dari peneliti terhadap penelitian pengembangan ini dapat digunakan sebagai salah satu alternatif sumber balajar dan penelitian ini dapat dieksperimenkan sehingga keefektifan dapat diketahui.
\end{abstract}

Kata Kunci: Media Video, Pencak Silat, Model ADDIE.

\section{PENDAHULUAN}

Pendidikan jasmani olahraga dan kesehatan (PJOK) merupakan bagian dari pendidikan nasional yang harus melibatkan unsur-unsur penting berupa fikiran dan tubuh (Junaedi, 2015). Pentingnya olahraga ini diterapkan di sekolah dilihat dari tujuan pembelajaran PJOK, yang mencakup berbagai faktor yaitu pengetahuan, sikap dan keterampilan.

Pentingnya olahraga ini diterapkan di sekolah dilihat dari tujuan pembelajaran PJOK, yang mencakup berbagai faktor yaitu pengetahuan, sikap dan keterampilan.

Sehingga guru harus memahami dan mengerti materi pembelajaran serta mengenali karakteristik peserta didik untuk menghasilkan situasi belajar lebih interaktif, serta dapat memenuhi tujuan yang ingin dicapai. Keikutsertaan peserta didik dalam proses pembelajaran merupakan tanda dari keberhasilan pembelajaran PJOK tersebut. Keberhasilan peserta didik tersebut dapat diukur dari pemahaman dan hasil belajarnya. Semakin tinggi tingkat keberhasilan memahami dan menguasai materi, semakin tinggi pula tingkat keberhasilan yang tercapai.

Seorang guru dituntut untuk memiliki pemahaman dan pengetahuan terkait mengenai media dan model pembelajaran agar mendapakan kemajuan dalam proses pembelajaran. Hal tersebut bisa membuat suasana belajar menyenangkan, aktif, kreatif serta inovatif bagi peserta didik, serta menjadikan peserta didik berpikir lebih tanggap dan melatih keterampilan sosial dan emosional supaya lebih baik dan tujuan dari pembelajaran pun akan tercapai. 
Jurnal Kejaora: Jurnal Kesehatan Jasmani dan Olah Raga

ISSN: 2541-5042 (Online)

ISSN: 2503-2976 (Print)

Volume 5 Nomor 2, Edisi November 2020

Pencak silat adalah salah satu cabang olahraga seni beladiri yang berasal dari Indonesia. Mardotillah Mila (2017), mengatakan bahwa pencak silat ialah aktivitas dalam masyarakat bersifat konkret, yang dapat di observasi.

Dalam pembelajaran pencak silat pada dasarnya mempunyai teknik-teknik dasar. Menurut Lubis, Johansyah (2004), mengatakan bahwa pencak silat terdapat tujuh teknik dasar, yaitu: pola langkah, serangan, kuda-kuda, tangkapan, sikap pasang, hindaran, dan belaan.

Setelah melakukan observasi di SMP Negeri 4 Sukasada pada peserta didik kelas VII tahun pelajaran 2019/2020 hasil belajarnya masih rendah dengan nilai ratarata 68,58 sedangkan KKM 65 , dan $8 \%$ diantaranya tidak lulus pada materi teknik dasar tendangan pencak silat, minat belajar peserta didik terutama pada materi teknik dasar tendangan pencak silat sangat minim karena pembelajaran yang dilakukan hanya berupa penjelasan dan kurangnya guru dalam memanfaatkan adanya media yang ada oleh karena itu peserta didik sulit memahami gerakan teknik dasar tendangan pencak silat.

Menurut Asyhar, Rayandra (2012), mengatakan bahwa dalam melakukan proses belajar secara efektif dan efisien diperlukan suatu sumber yang terencana sehingga terjadi lingkungan belajar yang kondusif yang dapat menyampaikan dan menyalurkan pesan yaitu disebut dengan media pembelajaran.

Media pembelajaran diperlukan dalam proses mengajar agar pembelajaran dapat berlangsung dengan mudah sesuai dengan kondisi kelas. Video pembelajaran menjadi media pembelajaran yang sesuai serta didalamnya terdapat tahapan proses pembelajaran yang terurai jelas dan terperinci. Media video pembelajaran dapat digunakan sebagai sumber belajar mandiri, dan mudah memahami materi teknik dasar tendangan pencak silat.

Berpijak pada latar belakang di atas rumusan masalah dalam penelitian ini yaitu:

1) Bagaimanakah rancang bangun pengembangan media video pembelajaran dengan model ADDIE pada teknik dasar 
yang sulit dijelaskan pada proses pembelajaran.

Menurut Turyati, dkk (2016), mengatakan bahwa fungsi indera pendengaran dan indera penglihatan dapat terangsang dengan audio-visual yang disebut dengan video. Menurut Busyaeri, dkk (2016), mengatakan bahwa video adalah suatu gambar hidup (bergerak), dengan menggunakan teknologi dalam penayangan dan perekamannya dan dapat dilihat. Menurut Suprapto, Hernu (2016), video adalah media audio-visual yang bergerak dan menampilkan gambar objek dan mengeluarkan suara. Kesimpulan dari video adalah media yang berbasis audio-visual terdapat gambar hidup serta suara yang sesuai.

Menurut Ayuningrum, Fiskha (2012), mengatakan bahwa pesan-pesan pembelajaran dapat disalurkan dengan baik dengan menggunakan media video pembelajaran. Menurut Asyhar, Rayandra (2012), mengatakan bahwa penyajikan informasi dalam bentuk suara dan visual.disebut dengan media video pembelajaran.

Menurut Mahadewi, dkk (2012) mengatakan bahwa, media video pembelajaran diartikan sebagai segala format media elektronik yang menampilkan gambar bergerak dengan penayangan suatu ide yang dapat merangsang pemikiran dan minat peserta didik. Berdasarkan paparan para ahli disimpulkan bahwa media video pembelajaran adalah kombinasi antara audio, tulisan dan gambar gerak elektronik yang digunakan untuk memotivasi minat belajar peserta didik. Media video pembelajaran adalah kombinasi antara audio, tulisan dan gambar gerak elektronik yang digunakan untuk memotivasi minat belajar peserta didik.

Menurut Kriswanto (2015), beladiri yang dapat dikembangkan, dibina dan merupakan warisan dari nenek moyang ialah pencak silat. Menurut Nusufi, Maimun (2015), mengatakan bahwa dalam pencak silat kemampuan fisik seperti kelincahan, kekuatan dan kecepatan yang mendominasi dalam olaharaga beladiri yang digunakan pada saat pertandingan. Sehingga dapat diambil kesimpulan bahwa pencak silat adalah suatu usaha dalam membela diri terhadap berbagai gangguan dan ancaman demi mencapai kehidupan yang aman dan nyaman serta taqwa kepada Tuhan Yang Maha Esa.

Pencak silat sangat erat kaitannya dengan kondisi fisik, mental, teknik dan kemampuan gerak. Terdapat macam-macam tendangan pencak silat yaitu: tendangan lurus, tendangan tusuk, tendangan kepret, tendangan jejag, tendangan gajul, tendangan $\mathrm{t}$, tendangan celorong, tendangan belakang, tendangan kuda, tendangan taji, tendangan sabit, tendangan baling, hentak bawah dan gejig.

\section{METODE}

Model pembuatan produk dalam penelitian pengembangan ini adalah model ADDIE. Pemilihan model ini didasarkan atas pertimbangan bahwa model ini disusun secara terprogram dengan urutan-urutan kegiatan yang sistematis dalam upaya pemecahan masalah belajar yang berkaitan dengan sumber belajar yang sesuai dengan kebutuhan dan karakteristik pembelajaran.

Alat yang digunakan untuk membantu proses pengumpulan data disebut dengan instrumen pengumpulan data. Alat yang digunakan dalam penelitian ini yaitu angket atau kuisioner dalam bentuk skala skor. Angket tersebut berisi item-item terkait dengan media video pembelajaran.

Penelitian pengembangan umumnya menggunakan dua teknik analisis data, yaitu 1) teknik analisis deskriptif kualitatif yang digunakan untuk mengolah data hasil review ahli mata pelajaran, ahli desain mata pelajaran, ahli media pembelajaran dan uji coba peserta didik. Teknik analisis data ini dilakukan dengan mengelompokkan informasi dari data kualitatif yang berupa masukan, tanggapan, kritik, dan saran perbaikan yang terdapat pada angket. Hasil analisis ini kemudian digunakan untuk merevisi produk yang dikembangkan, dan 2) analisis deskriptif kuantitatif yang digunakan untuk mengolah data yang diperoleh melalui angket dalam bentuk deskriptif persentase.

Menurut Mustofa dan Kurniawan (2020) pengembangan Model ADDIE 
Jurnal Kejaora: Jurnal Kesehatan Jasmani dan Olah Raga

ISSN: 2541-5042 (Online)

ISSN: 2503-2976 (Print)

Volume 5 Nomor 2, Edisi November 2020

dipopulerkan oleh Robert M. Branch meliputi 5 tahap yaitu:

\section{Analysis (analisis)}

Berdasarkan hasil observasi ditunjukkan bahwa hasil belajar rendah pada peserta didik kelas VII, 8\% dari 108 peserta didik dinyatakan tidak tuntas dan $92 \%$ dinyatakan tuntas dengan nilai rata-rata peserta didik pada materi teknik dasar pencak silat yaitu 68,58 dengan KKM 65. Hal ini ditunjukkan dengan rendahnya hasil belajar pesertadi SMP Negeri 4 Sukasada khususnya materi teknik dasar tendangan pencak silat. Masalah penyebab nilai peserta didik rendah karena rendahnya pemanfaatan media pembelajaran, sehingga proses pembelajaran menjadi tidak menarik dan pembelajaran cenderung berjalan kurang efektif dan membuat siswa cepat merasa bosan serta tidak termotivasi untuk mempelajari materi ajar tersebut. Adanya fasilitisas yang kurang dimanfaatkan dengan optimal khususnya pada pembelajaran PJOK.

\section{Design (desain)}

Untuk mengatasi permasalahan yang ada di sekolah, peneliti mencari solusi dan mulai merancang naskah video pembelajaran seperti pemilihan dan penetapan software. Pemilihan software dalam media video pembelajaran ini menggunakan Movavi Video Editor Businnes 15.5.0. Mengembangkan naskah video pembelajaran/storyboard dan flochart. Storyboard adalah rangkaian sketsa yang terdapat didalam tabel untuk menggambarakan urutan cerita dalam media video pembelajaran. flowchart adalah bagan proses yang menunjukkan suatu urutan, prosedur atau aliran proses. Flowchart menggunakan anotasi-anotasi semisal persegi, panah, oval, wajik dll. Rancangan tersebut dibuat yang nantinya akan menjadikan sebuah produk berupa video pembelajaran yang diharapkan dapat membantu guru dan peserta didik dalam proses pembelajaran dan membantu peserta didik dalam meningkatkan minat belajar.

\section{Development (pengembangan)}

Setelah media video jadi sebelum di ujicobakan ke peserta didik, peneliti

melakukan validasi kepada para ahli yaitu ahli isi/materi pembelajaran, ahli media pembelajaran dan ahi desain pembelajaran untuk mengetahui kelayakan dari media video pembelajaran yag sudah dibuat. Selanjutnya apabila terdapat saran dan masukan dari para ahli, maka peneliti harus melakukan revisi produk sesuai dengan saran dan masukan agar produk yang dibuat menjadi lebih sempurna dan layak digunakan.

\section{Implementation (implementasi)}

Pada tahap ini peneliti menerapkan media video yang sudah direncanakan dan dikembangkan untuk diuji cobakan kepada peserta didik, untuk mengetahui apakah media video yang dikembangkan ini sudah sesuai dengan apa yang direncanakan dan membantu dalam proses pembelajaran. Tahap uji coba produk ini dilakukan dengan tiga tahap yaitu uji coba perorangan dilakukan oleh 3 orang peserta didik, uji coba kelompok kecil dilakukan oleh 8 orang peserta didik dan uji coba kelompok besar dilakukan oleh 24 orang peserta didik.

\section{Evaluation (evaluasi)}

Tahap evaluasi merupakan tahapan akhir dari sebuah penelitian, tahap ini dilakukan untuk melihat apakah tujuan dan sasaran dari produk ini sudah tercapai atau belum dengan cara menyimpulkan dan melihat hasil presentasi dari angket yang telah disebarkan kepada para ahli dan peserta didik. Dengan demikian peneliti dapat mengetahui keberhasilan dari media video pembelajaran yang dikembangkan oleh peneliti.

\section{HASIL DAN PEMBAHASAN}

Berdasarkan hasil observasi di SMP Negeri 4 Sukasada bahwa hasil belajar peserta didik kelas VII masih tergolong rendah, peneliti mendapatkan permasalahan diantaranya yaitu: 1) pembelajaran yang digunakan guru menggunakan teknik penyampaian dengan metode ceramah. 2) sarana dan prasana yang ada di sekolah tidak berfungsi secara optimal seperti adanya LCD dan proyektor yang tidak dimanfaatkan dengan baik. 3) guru kurang aktif dalam 
Jurnal Kejaora: Jurnal Kesehatan Jasmani dan Olah Raga

ISSN: 2541-5042 (Online)

ISSN: 2503-2976 (Print)

Volume 5 Nomor 2, Edisi November 2020

memanfaatkan media pembelajaran pada proses pembelajaran yang belangsung.

$$
\text { Maka dari itu peneliti }
$$

mengembangkan produk berupa media video pembelajaran pencak silat pada materi teknik dasar tendangan pencak silat sebagai alat bantu bagi peserta didik dan guru dalam proses pembelajaran berlansung, pada proses pembelajaran peserta didik lebih mudah dalam memahami materi yang diajarkan oleh guru khususnya yaitu materi teknik dasar tendangan pencak silat, pada proses pembelajaran, media video menjadi media interaktif yang dapat menarik minat peserta didik sehingga tidak merasa bosan dan jenuh, media video pembelajaran dapat meningkatkan hasil belajar peserta didik.

\begin{tabular}{llll}
\multicolumn{4}{c}{ Tabel 1. Hasil Uji Para Ahli } \\
\hline No & Ahli & Presentasi & Kualifikasi \\
\hline 1 & Ahli Mata & $94 \%$ & Sangat \\
& Pelajaran & & Baik \\
\hline 2 & Ahli Media & $90 \%$ & Sangat \\
& Pembelajaran & & Baik \\
\hline 3 & Ahli Desain $94 \%$ & Sangat \\
& Pembelajaran & & Baik \\
\hline
\end{tabular}

Hasil penelitian ini menunjukkan bahwa validitas bahan ajar yang dikembangkan ditinjau dari aspek isi mata pelajaran berada pada kategori sangat baik dengan perolehan presentase sebesar $94 \%$. Adapun kendala dari uji ahli isi mata pelajaran, yaitu: 1) istilah "macam-macam dalam tendangan pencak silat" sebaiknya diganti dengan "teknik dasar tendangan pencak silat". 2) hapus "tulisan yang ada dalam video pembelajaran", karena kalimat tersebut bisa berarti lebih dari 7 teknik dasar dalam pencak silat. 3) sikap awal dan sikap akhir jelaskan dengan "sikap tegak" berapa? karena dalam pencak silat "sikap tegak" terdapat istilah atau nama. 4) pada tendangan lurus dan tendangan tusuk gerakannya hampir sama, maka jelaskan pada narasinya dengan baik. Misalnya gunakan perkenaan sebagai indikator untuk membedakan. 5) pengetikan "di" yang digandengkan dengan kata tempat seharusnya "di" dipisah dengan kata yang menyertainya. 6) pengisian suara pada tendangan jejag menit 05.33-05.34, suaranya double. 7) secara keseluruhan masih kurang setuju dengan gerakan kuda-kuda pada sikap pelaksanaan. Karena yang disebutkan dalam video adalah kuda-kuda depan, namun dalam gerakan tidak kuda-kuda depan. Solusi dari permasalahan tersebut, yaitu peneliti melakukan revisi produk sesuai dengan hasil review dari ahli isi mata pelajaran.

Aspek desain pembelajaran berada pada kategori sangat baik dengan perolehan presentase sebesar 94\%. Adapun kendala dari uji ahli media pembelajaran, yaitu: 1) pada menit ke 01.08 agar fokuskan ke teks. 2) gunakan teks kuning atau putih stroke hitam. 3) gunakan sistem penomoran pada sebuah rincian. 4) presenter memahami dan menyimpulkan materi serta memberikan latihan dan tugas akhir. Solusi dari permasalahan tersebut, yaitu peneliti melakukan revisi produk sesuai dengan hasil review dari ahli media pembelajaran.

Aspek media pembelajaran berada pada kategori sangat baik dengan perolehan presentase sebesar $90 \%$. Adapun kendala dari uji ahli desain pembelajaran, yaitu: 1) bagian akhir cashing beri garis besar isi media dan petunjuk penggunaan. 2) pada kredit titik diakhir ditambahkan dosen pembimbing dan pejabat di lingkungan FOK. 3) evalusi cantumkan pada video atau buku panduan. Solusi dari permasalahan tersebut, yaitu peneliti melakukan revisi produk sesuai dengan hasil review dari ahli desain pembelajaran.

Sedangkan uji coba perorangan, uji coba kelompok kecil dan uji coba kelompok besar tidak dapat dilaksanakan karena adanya Pandemi covid 19 yang mengharuskan peserta didik untuk belajar di rumah secara daring/online.

Tabel 2. Konversi Tingkat Pencapaian dengan Skala 5

\begin{tabular}{lll}
\hline No & Tingkat Pencapaian & Kualifikasi \\
\hline 1 & $85 \%-100 \%$ & Sangat Baik \\
\hline 2 & $75 \%-84 \%$ & Baik \\
\hline 3 & $65 \%-74 \%$ & Cukup Baik \\
\hline 4 & $55 \%-64 \%$ & Kurang Baik \\
\hline 5 & $0 \%-54 \%$ & $\begin{array}{l}\text { Sangat Kurang } \\
\text { Baik }\end{array}$ \\
\hline
\end{tabular}

\section{KESIMPULAN}

Rancang bangun media video pembelajaran menggunakan model 
Jurnal Kejaora: Jurnal Kesehatan Jasmani dan Olah Raga

ISSN: 2541-5042 (Online)

ISSN: 2503-2976 (Print)

Volume 5 Nomor 2, Edisi November 2020

pengembangan ADDIE yang terdiri dari 5 tahap yaitu 1. Analisis (analyze), 2. Desain (design), 3. Pengembangan (development), 4. Implementasi (implementation), 5. Evaluasi (evaluation). produk yang dihassilkan yaitu video pembelajaran PJOK pada materi teknik dasar tendangan pencak silat yang diharapkan dapat dijadikan sebagai alat bantu bagi peserta didik dan guru dalam proses pembelajaran berlansung, pada proses pembelajaran peserta didik lebih mudah dalam memahami materi yang diajarkan oleh guru khususnya yaitu materi teknik dasar tendangan pencak silat, pada proses pembelajaran, media video menjadi media interaktif yang dapat menarik minat peserta didik sehingga tidak merasa bosan dan jenuh, media video pembelajaran dapat meningkatkan hasil belajar peserta didik.

Validitas media video pembelajaran ini mendapat tingkat presentase yaitu 1) sebesar 94\% yang termasuk ke dalam kategori sangat baik menurut ahli isi/materi, 2) sebesar $90 \%$ yang termasuk ke dalam kategori sangat baik menurut ahli media pembelajaran, 3) sebesar $94 \%$ yang termasuk ke dalam kategori sangat baik menurut ahli desain pembelajaran.

Adapun saran yang disampaikan berdasarkan pengembangan media video pembelajaran teknik dasar tendangan pencak silat ini adalah: bagi peserta didik disarankan menggunakan media video pembelajaran ini sebagai salah satu sumber belajar mandiri, karena peserta didik bisa belajar media video pembelajaran ini kapan saja dan dimana saja.

Bagi guru disarankan memanfaatkan media video pembelajaran ini untuk meningkatkan motivasi belajar peserta didik guna meningkatkan kemampuan belajar PJOK. Bagi sekolah disarankan agar menyimpan media video pembelajaran ini untuk dijadikan salah satu alternatif sumber belajar yang bisa membantu guru pada penyampaian materi. Bagi peneliti lainnya diharapkan dapat mengeksperimenkan penelitian ini agar bisa diketahui kefektifannya media video pembelajaran teknik dasar tendangan pencak silat untuk meningkatkan prestasi belajar peserta didik.

\section{UCAPAN TERIMA KASIH}

Dalam proses pembuatan skripsi ini, sangat banyak mendapat bantuan dari berbagai pihak. Oleh karena itu, pada kesempatan ini diucapkan terimakasih yang sebesar-besarnya dan setulus-tulusnya kepada yang terhormat:

1. Prof. Dr. I nyoman Jampel, M.Pd., Rektor universitas Pendidikan Ganesha yang telah memberikan kesempatan kepada peneliti untuk mengikuti pendidikan pada Program Studi Pendidikan Jasmani Kesehatan Dan Rekreasi Fakultas Olahraga Dan Kesehatan.

2. I Ketut Budaya Astra, S.Pd., M.Or., selaku Dekan Fakultas Olahraga dan Kesehatan sekaligus pembimbing I yang telah memberikan bimbingan, motivasi, saran dan masukan dalam penyelesaian skripsi ini.

3. I Gede Suwiwa, S.Pd., M.Pd., selaku Koordinator Program Studi Pendidikan Jasmani, Kesehatan dan Rekreasi sekaligus sebagai pembimbing II yang telah memberikan bimbingan, motivasi, saran dan masukan dalam penyelesaian skripsi ini.

4. Seluruh staff dosen dan pegawai di Fakultas Olahraga dan kesehatan yang telah memberikan pengetahuan dan membantu kelancaran penelitian ini.

5. Keluarga besar yang telah memberikan dorongan secara moril dan materu sehingga skripsi in dapat diselesaikan

6. Semua pihak yang tidak dapat peneliti sebutkan satu persatu yang telah banyak memberikan bantuan dalam penelitian ini

\section{DAFTAR PUSTAKA}

$\begin{array}{crr}\text { Asyhar, } \quad \text { R. } & \text { (2012). } & \text { Kreatif } \\ \text { Mengembangankan } & \text { Media } \\ \text { Pembelajaran. Jakarta: } & \text { Referensi } \\ \text { Jakarta. } & & \end{array}$

Atapukang, N. (2016). Kreatif Membelajarkan Pembelajar dengan Menggunakan Media Pembelajaran yang Tepat sebagai Solusi dalam Berkomunikasi. Jurnal Media Komunikasi Geografi. VOL. 17. (2): 3.

Ayuningrum, F. (2012). Pengembangan Media Video Pembelajaran Untuk Siswa Kelas X pada Kompetensi 
Jurnal Kejaora: Jurnal Kesehatan Jasmani dan Olah Raga

ISSN: 2541-5042 (Online)

ISSN: 2503-2976 (Print)

Volume 5 Nomor 2, Edisi November 2020

Mengolah Soup Kontinental di SMK N 2 Godean. Yogyakarta: UNY.

Busyaeri, dkk. (2016). Pengaruh Penggunaan Video Pembelajaran Terhadap Peningkatan Hasil Belajar Mapel IPA di MIN Kroya Cirebon. Jurnal Pendidikan Guru MI. VOL. 3(1): 12.

Junaedi, A. (2015). Survei Tingkat Kemajuan Pendidikan Jasmani, Olaharaga dan Kesehatan Di SMA, SMK dan MA Negeri Se-Kabupaten Gresik. Jurnal. VOL. 3. (3): 3.

Kriswanto, E.S. (2015). Pencak Silat: Sejarah dan Perkembangan Pencak Silat, Teknik-Teknik dalam Pencak Silat. Pengetahuan Dasar Pertandingan Pencak Silat. Yogyakarta: Pustaka Baru Press.

Lubis, J. (2004). Pencak Silat Panduan Praktis. Jakarta: PT Raja Grafindo Persada 2004.

Mahadewi, dkk. (2012). Media Video Pembelajaran. Singaraja: UNDIKSHA.

Mahnun, N. (2012). Media Pembelajaran (Kajian Terhadap Langkah-langkah Pemilihan Media dan Implementasinya dalam Pembelajaran). Jurnal Pemikiran islam. VOL. 37. (1):2.

Mardotillah, M. (2016). Silat Identitas Budaya, Pendidikan, Seni Bela Diri, dan Pemeliharaan Kesehatan. Jurnal Antropologi. VOL. 18 (2): 2.

Mustofa, H.K. dan Kurniawan, A. (2020). Pengembangan Bola Banel Sebagai Media Pembelajaran Bola Voli Di SDN 1 Buluagung. Jurnal Kejaora: Jurnal Kesehatan Jasmani dan Olah Raga. VOL.--5.-(1): 2.

Nusufi, M. (2015). Hubungan Kelentukan dengan Kemampuan Kecepatan Tendangan Sabit pada Atlet Pencak Silat Binaan Dispora Aceh (Pplp dan Diklat) Tahun 2015. Jurnal IImu Keolahragaan. VOL. 14. (1): 2.

Purwanto, D. (2017). Pengembangan Model Latihan Sundulan (Heading) untuk Pemula pada Peserta Extrakulikuler Sepak Takraw di SMP Negeri 6 Palu. Jurnal Penjaskesrek. VOL. 4. (2): 5.

Suandi, dkk. (2016). Pedoman Penulisan Karya Ilmiah Tugas Akhir, Skripsi, 